\title{
Changes in organic compounds during leaf litter leaching: laboratory experiment on eight plant species of the Sudano-guinea Savannas of Ngaoundere, Cameroon
}

\begin{abstract}
Ibrahima $A^{*(1)}$, Biyanzi $P^{(2)}$, Halima $M^{(1)}$
Abstract: A laboratory experiment was carried out on the leaf litter of 8 agroforestry plant species of the Sudano-guinea Savannas of Ngaoundere in order to compare patterns of their water absorption and dynamics of four important energetic organic compounds (soluble sugars, cellulose, phenol and lignin) among these plant species during the leaching phase and to determine the influence of initial litter properties on these processes. To this end, 168 samples of leaf litter (5.00 $\pm 0.01 \mathrm{~g})$ of Annona senegalensis, Lophira lanceolata, Syzygium guineense var. guineense, Syzygium guineense var. macrocarpum, Vitellaria paradoxa, Vitex doniana, Vitex madiensis and Ximenia americana were immersed for 15 days in distilled water at a temperature of $23{ }^{\circ} \mathrm{C}$ and relative humidity of $65 \pm 1 \%$. Three samples of each plant species were taken at 1,6 , 24, 72, 168, 240 and 360 hours. Depending on the species, water absorption capacity after $360 \mathrm{~h}$ of leaching varied from 162.77 (S. g. var. macrocarpum) to $264.00 \%$ ( $V$. madiensis) of dry litter mass. The release of water-soluble substances varied between 9.61 (L. lanceolata) and 34.12\% (X. americana). Water absorption and release of water-soluble substances rate constants were the highest in $V$. madiensis $\left(0.32 \mathrm{~h}^{-1}\right.$ and $\left.0.25 \mathrm{~h}^{-1}\right)$ and the lowest one respectively in S. g. guineense $\left(0.03 \mathrm{~h}^{-1}\right)$ and $S$. g. var. macrocarpum $\left(0.006 \mathrm{~h}^{-1}\right)$. Organic compound of original litter also varied significantly among species and decreased with leaching time for water-soluble sugars and phenols, while increased for cellulose and lignin. Water absorption by litter was significantly correlated with initial water-soluble sugars and phenol content, leaf litter area and thickness. The release of water-soluble substances by litters was also correlated with initial water-soluble sugars, water content and leaf litter area. The leaching rate constant was correlated with that of water absorption. These preliminary results lead to a better understanding of the litter decomposition processes of agroforestry plant species of Ngaoundere and thus help in making the most appropriate choice of indigenous plant species for domestication that could help to improve soil fertility and eventually to protect the biodiversity.
\end{abstract}

Keywords: litter, leaching, quality, organic compounds, Sudano-guinea savanna, Cameroon

\section{Introduction}

Litter decomposition represents an important process in the biogeochemical cycling.

${ }^{(1)}$ Department of Biological Sciences, Faculty of Science, The University of Ngaoundere, P.O.Box 454 Ngaoundere, Cameroon; (2) Department of Food and Nutritional Sciences, National High School of AgroIndustrial Sciences, The University of Ngaoundere, P.O.Box 455 Ngaoundere, Cameroon.

*Corresponding Author: Adamou Ibrahima (aibrahima@hotmail.com).

Citation: Ibrahima A, Biyanzi P, Halima M, 2008. Changes in organic compounds during leaf litter leaching: laboratory experiment on eight plant species of the Sudano-guinea Savannas of Ngaoundere, Cameroon. iForest 1: 27-33 [online: Feb 28, 2008] URL:

http://www.sisef.it/iforest/
During this process immobilized nutrients in litter are released from litter to soil and made available to plants and soil micro-organisms (Waring \& Schlesinger 1985). The litter decay rate is a factor that largely determines soil fertility (Bossa et al. 2005) and its regulation plays an important role in agro-ecosystem functioning, notably in poor soil of Sudano-guinea savannas of Ngaoundere.

The initial phase of litter decomposition, so called leaching stage, has an important influence on subsequent processes and it may be responsible for a substantial part of mass loss from litter during the early stages of litter decomposition (MacLean \& Wein 1978, Saini 1989). Bernhard-Reversat (1993) reported that mass loss from fresh litter was equal to the loss of soluble compounds during the first weeks of in situ decay. This emphasized the dependence of the early decomposition processes on soluble organic compound release. Removal of soluble matter through leaching could thus impede or delay litter decomposition compared with litter in which soluble remain long enough to be metabolized. During the leaching phase, litter releases both inorganic elements, such as $\mathrm{Ca}$, $\mathrm{K}, \mathrm{Mg}$, and simple organic compounds, such as protein and water-soluble sugars and phenols (Mangenot \& Toutain 1980, Bernhard-Reversat et al. 2003). These are energetic compounds, necessary for the decomposers which will later decompose recalcitrant compounds such as lignin and cellulose (Berg \& Wessen 1984).

Water-soluble compounds released by litter varies among species or specie groups (Ibrahima et al. 1995, Bernhard-Reversat 1999). It is also known that not all water-soluble compounds are leached with equal facility. Among the organic compounds, carbohydrates are easily and rapidly leached. They are generally easily and rapidly degraded in early stages of litter decomposition by fast growing microorganisms that may require a high concentration of nitrogen (Swift et al. 1979). Cellulose and lignin, the most abundant components of litter, are slowly decomposed. Nevertheless, because lignin physically protects most of the cellulose and hemicellulose from enzymatic hydrolysis, neither group of compounds decompose independently (Cooke \& Whipps 1993). High concentrations of polyphenols and lignin lead to low decomposition rate (Swift et al. 1979, Kalburtji et al. 1999).

However, in spite of the importance of the leaching phase in litter decomposition processes, information concerning leaching of organic compounds of litter of indigenous plant species of the Sudano-guinea savannas of Ngaoundere, particularly potential agroforestry plant species which have likely, in the future, to be integrated in farming systems in order to improve or restore soil fertility, is very limited, excepting that of Ibrahima et al. (2003). Their study was carried out on water absorption and mass loss of nine litters during $240 \mathrm{~h}$ of leaching, and the relations between physical characteristics of leaf and leaching rates. The aim of the present study is to determine the dynamics of four important energetic organic compounds (soluble sugars, cellulose, phenol and lignin) during $360 \mathrm{~h}$ of litter leaching in laboratory, to compare the patterns of this process among these plant species and to determine relations between physical characteristics of litter and leaching.

\section{Materials and methods}

\section{Leaf litter selection}

In this study, only fresh fallen leaf litter of 
eight socio-economical plant species of the Sudano-guinea savannas of Ngaoundere was used. The experiment involved 8 species: deciduous broad-leaved including three tree species (Lophira lanceolata, Vitex doniana and Vitellaria paradoxa) and four shrub species (Annona senegalensis, Syzygium guineense var. macrocarpum, Vitex madiensis and Ximenia americana) and an evergreen broad-leaved tree species (Syzygium guineense var. guineense). The distribution area of S.g. var. guineense Engl. (Myrtaceae) and $V$. doniana Sweet (Verbenaceae) is the forest gallery, while $A$. senegalensis Pers. (Annonaceae), L. lanceolata Vann Tiegh ex Keay (Ochnaceae), S. guineense var. macrocarpum Engl. (Myrtaceae), V. madiensis Oliv. (Verbenaceae), V. paradoxa Vaertu (Sapotaceae) and $X$. americana Linn (Olacaceae) are located in the upland savanna. The eight species play a great socioeconomical role. They are a source of income, food, firewood, medicinal substances and soil fertility indicators for the farmers of this region (Yonkeu 1993, Pabame 2002) The farmers start now to conserve these plant species in farms.

\section{Leaching experiment}

New litter fall samples were collected directly from forest floor in the Ngaoundere humid savannas, next to the University of Ngaoundere, during maximum leaf fall period (November 2002 - January 2003). This period corresponds to dry season and soil was very dried; no leaching was occurred from new litter. The site, Dang, is located 15 $\mathrm{km}$ from Ngaoundere Town. Litter was airdried and stored in the laboratory before use. For each species, twenty one leaf-litter samples of $5.00 \pm 0.01 \mathrm{~g}$ were weighed and submerged in plastic glass bottles $(15 \mathrm{~cm}$ high and $13 \mathrm{~cm}$ wide), each containing 1 litre of distilled water, which was renewed every $24 \mathrm{~h}$. The bottles were maintained in the laboratory for 15 days at room temperature of $23{ }^{\circ} \mathrm{C}$ and relative humidity of $65 \pm 1 \%$.
Three other samples of each species were oven dried $\left(48 \mathrm{~h}\right.$ at $\left.60{ }^{\circ} \mathrm{C}\right)$ to determine their initial water content and initial dry mass. Three sample replicates of each species were sampled from bottles after $1 \mathrm{~h}, 6 \mathrm{~h}, 24 \mathrm{~h}, 72$ h, $168 \mathrm{~h}, 240 \mathrm{~h}$ and $360 \mathrm{~h}$. After removal, the samples of each litter were weighed wet, after removing surface water by pressing them between two sheets of filter paper. Then they were dried $\left(48 \mathrm{~h}\right.$ at $\left.60^{\circ} \mathrm{C}\right)$ and reweighed to obtain their dry weight. The water content and remaining dry mass were calculated.

For each species, 3 replicates (each of 10 leaf litter) were oven-dried $\left(48 \mathrm{~h}\right.$ at $\left.60{ }^{\circ} \mathrm{C}\right)$, then weighed and their thickness measured by calliper. To avoid fragmentation, leaf-litter was moistened again, spread out and then the leaf areas were measured using a planimeter (Area meter, MK2).

\section{Chemical analysis}

The samples of dry initial litters and those collected after $168 \mathrm{~h}$ and $360 \mathrm{~h}$ of incubation $(\mathrm{n}=72)$ were ground in Waring Commercial Blender and sieved at $1 \mathrm{~mm}$. The concentrations of water-soluble sugar, phenol, cellulose and lignin were respectively determined by Dubois et al. (1965) method, by FolinCiocalteu reagent (Marigo 1973), by colorimetric method (Updegraff 1969) and by van Soest's (1965) and detergent method.

\section{Statistical analysis}

Changes in litter water content (WC in \% dry mass) in relation to leaching time (in hours) were fitted to the following simple exponential model (e.g., Ibrahima et al. 1995):

$$
W C=A\left[1-\exp \left(-k_{e} t\right)\right]
$$

where $A$ is the maximum water absorption capacity of litter (or Asymptote), $k_{\mathrm{e}}$ and $t$ are respectively the litter water absorption rate constant and the time of water absorption.

The litter mass remaining (LMR expressed

Fig. 1 - Changes in litter WC with leaching time in the 8 agroforestry species studied. AS: A. senegalensis; LL: L.

lanceolata; SG: S.g. guineensis; SM: S. g. macrocarpum; VP: $V$. paradoxa; VD: V. doniana $; \mathrm{VM}$ : $V$. madiensis; XA: X. americana.

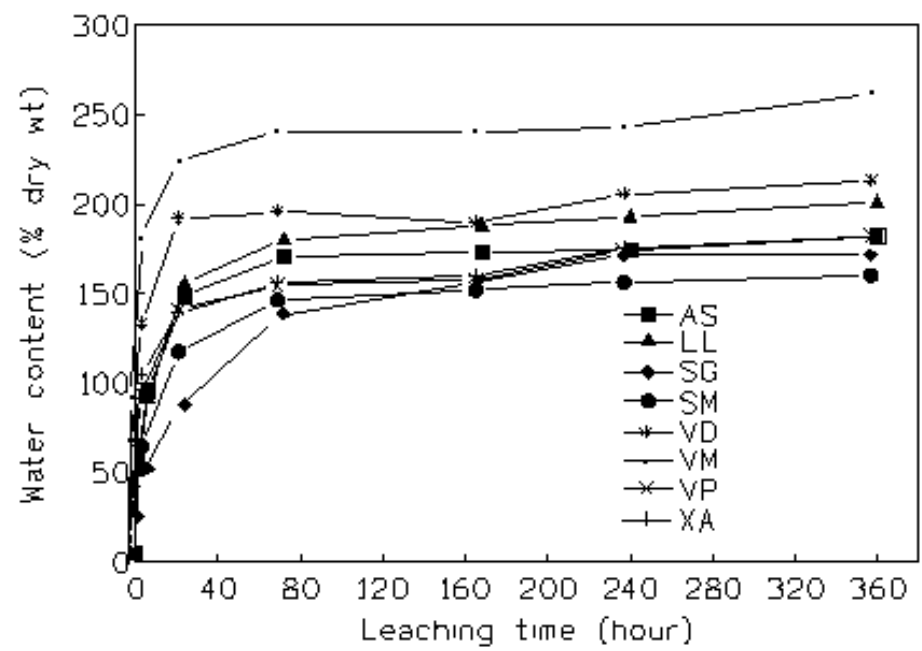

as a percentage of the initial mass) in relation to leaching time (in hours) was fitted to the following simple exponential model (Ibrahima et al. 2003, modified):

$$
L M R=B \cdot \exp \left(-k_{s} t\right) C
$$

where $k_{\mathrm{s}}$ is the leaching rate constant, $\mathrm{B}$ and $\mathrm{C}$ are respectively the compartments of water soluble and resistant substances (lignin, cellulose and other compounds not determined).

Because their coefficients of determination were highly significant, both equations were adopted in study.

A multiple comparison among the fitted constants was carried out using the $T^{\prime}$ '-method (Sokal \& Rohlf 1981). ANOVA, following by Scheffe's mean comparison test at 5\% were used to compare the species.

The concentrations of the water-soluble sugars, phenol, cellulose and lignin compounds at the last sampling time (after $360 \mathrm{~h}$ of leaching) were compared to those measured in the initial litter for each species (Student $t$ test). The loss of constituents was calculated as difference between final absolute amount and initial one of each component (g) and the same difference was also expressed as percentage of initial amount (\%). A Student provided a test of the significance of the losses of constituents between the start of the experiment and after $360 \mathrm{~h}$ of leaching.

Pearson's coefficients were calculated between water absorption and leaching rate constants and physical and chemical characteristics of initial leaf litter. Multiple regression (stepwise) models were also used to determine relationships between these parameters. Relationships between maximum water absorption and LMR after $360 \mathrm{~h}$ were also determined.

\section{Results}

\section{Initial litter properties}

Excepting lignin content, all initial litter properties presented in this study differed significantly among plant species (Tab. 1). Initial water content (IWC) varies from $4.12 \%$ in $X$. americana to $7.30 \%$ in $S$. $g$. macrocarpum. The highest values of leaf litter area $\left(127.92 \mathrm{~cm}^{2}\right)$ and thickness $(0.47$ $\mathrm{mm})$ are found in $A$. senegalensis shrub and the lowest ones in X. americana shrub (15.92 $\mathrm{cm}^{2}$ and $0.14 \mathrm{~mm}$ ). Water soluble sugar contents vary significantly from $S$. g. macrocarpum $(5.90 \%)$ to $V$. paradoxa $(12.63 \%)$ and those of phenol from $V$. madiensis $(1.24 \%)$ to $S$. g. macrocarpum $(3.69 \%)$. The lowest values of cellulose and lignin contents were found in litter of $V$. paradoxa (respectively 1.46 and $1.05 \%$ ) and the highest ones were found respectively in those of $V$. doniana (3.28\%) and L. lanceolata (5.37\%). 
Tab. 1 - Physical and chemical properties of initial litters (0h) and organic compounds of litter obtained after $360 \mathrm{~h}$ of leaching. t: student test between litters at $0 \mathrm{~h}$ and $360 \mathrm{~h}$ of incubation; Standard Errors in parentheses; ns: non significant; ns: non significant; $* \mathrm{P}<0.05$; $* * \mathrm{P}<$ $0.01 ; * * * \mathrm{P}<0.001$. Different letters indicate significant differences among different species for initial litters or for litters after $360 \mathrm{~h}$ of incubation. AS: A. senegalensis; LL: L. lanceolata; SG: Syzygium guineense var. guineense; SM: S. guineense var. macrocarpum; VD: V. doniana; VM: V. madiensis; VP: V. paradoxa and XA: X. americana.

\begin{tabular}{|c|c|c|c|c|c|c|c|c|c|c|}
\hline \multirow{2}{*}{ Parameter } & \multirow{2}{*}{ Time } & \multicolumn{3}{|c|}{ Deciduous broad-leaved trees } & \multicolumn{4}{|c|}{ Deciduous broad-leaved shrubs } & \multicolumn{2}{|c|}{ Evergreen trees } \\
\hline & & $\mathbf{L L}$ & VD & VP & $\mathbf{A S}$ & SM & VM & $\mathbf{X A}$ & SG & $\mathbf{F}$ \\
\hline Initial WC (\%) & $0 \mathrm{~h}$ & $\begin{array}{c}5.27 \\
(0.89)^{\mathrm{bc}}\end{array}$ & $\begin{array}{c}5.35 \\
(0.15)^{\mathrm{c}}\end{array}$ & $\begin{array}{c}6.26 \\
(0.84)^{\mathrm{bc}}\end{array}$ & $\begin{array}{c}5.14 \\
(0.14)^{\mathrm{c}}\end{array}$ & $\begin{array}{c}7.30 \\
(0.13)^{\mathrm{a}}\end{array}$ & $\begin{array}{c}4.90 \mathrm{~b} \\
(0.84)^{\mathrm{c}}\end{array}$ & $\begin{array}{c}4.12 \\
(0.56)^{\mathrm{c}}\end{array}$ & $\begin{array}{c}6.46 \\
(0.36)^{b}\end{array}$ & $6.58 * *$ \\
\hline Area $\left(\mathrm{cm}^{2}\right)$ & $0 \mathrm{~h}$ & $\begin{array}{c}116.08 \\
(36.73)^{\mathrm{ab}}\end{array}$ & $\begin{array}{c}51.41 \\
(36.46)^{\mathrm{c}}\end{array}$ & $\begin{array}{c}105.92 \\
(23.24)^{\mathrm{ab}}\end{array}$ & $\begin{array}{c}127.92 \\
(14.64)^{\mathrm{a}}\end{array}$ & $\begin{array}{c}95.83 \\
(16.21)^{b}\end{array}$ & $\begin{array}{c}43.36 \\
(22.34)^{\mathrm{c}}\end{array}$ & $\begin{array}{c}15.92 \\
(3.07)^{\mathrm{d}}\end{array}$ & $\begin{array}{c}84.67 \\
(18.47)^{\mathrm{b}}\end{array}$ & $21.10 * * *$ \\
\hline Thickness (mm) & $0 \mathrm{~h}$ & $\begin{array}{c}0.21 \\
(0.02)^{\mathrm{c}}\end{array}$ & $\begin{array}{c}0.40 \\
(0.07)^{\mathrm{ab}}\end{array}$ & $\begin{array}{c}0.15 \\
(0.03)^{\mathrm{d}}\end{array}$ & $\begin{array}{c}0.47 \\
(0.04)^{\mathrm{a}}\end{array}$ & $\begin{array}{c}0.35 \\
(0.03)^{\mathrm{b}}\end{array}$ & $\begin{array}{c}0.33 \\
(0.05)^{\mathrm{b}}\end{array}$ & $\begin{array}{c}0.14 \\
(0.03)^{\mathrm{d}}\end{array}$ & $\begin{array}{c}0.36 \\
(0.04)^{\mathrm{b}}\end{array}$ & $19.56^{* * *}$ \\
\hline \multirow[t]{3}{*}{ Soluble sugars $(\%)$} & $0 \mathrm{~h}$ & $\begin{array}{c}7.91 \\
(1.12)^{\mathrm{cd}}\end{array}$ & $\begin{array}{c}10.48 \\
(0.03)^{\mathrm{ab}}\end{array}$ & $\begin{array}{c}12.63 \\
(0.37)^{\mathrm{a}}\end{array}$ & $\begin{array}{c}9.54 \\
(0.17)^{\mathrm{bc}}\end{array}$ & $\begin{array}{c}5.90 \\
(1.14)^{\mathrm{d}}\end{array}$ & $\begin{array}{c}11.05 \\
(0.97)^{\mathrm{ab}}\end{array}$ & $\begin{array}{c}10.99 \\
(2.23)^{\mathrm{ab}}\end{array}$ & $\begin{array}{c}6.88 \\
(0.84)^{d}\end{array}$ & $9.25 * *$ \\
\hline & $360 \mathrm{~h}$ & $\begin{array}{c}4.02 \\
(0.11)^{\mathrm{bc}}\end{array}$ & $\begin{array}{c}4.15 \\
(0.46)^{b}\end{array}$ & $\begin{array}{c}2.46 \\
(0.68)^{\mathrm{d}}\end{array}$ & $\begin{array}{c}5.86 \\
(0.15)^{\mathrm{a}}\end{array}$ & $\begin{array}{c}3.81 \\
(0.52)^{\mathrm{bc}}\end{array}$ & $\begin{array}{c}3.28 \\
(0.20)^{\mathrm{bcd}}\end{array}$ & $\begin{array}{c}3.76 \\
(0.14)^{\mathrm{bc}}\end{array}$ & $\begin{array}{c}3.01 \\
(0.82)^{\mathrm{cd}}\end{array}$ & $9.46^{* *}$ \\
\hline & $t$ & $4.91 *$ & $19.22 * *$ & $18.67 * *$ & $22.92 * * *$ & $2.37 \mathrm{~ns}$ & $11.13 * *$ & $4.58^{*}$ & $4.66^{*}$ & - \\
\hline \multirow[t]{3}{*}{ Phenol (\%) } & $0 \mathrm{~h}$ & $\begin{array}{c}1.84 \\
(0.27)^{\mathrm{c}}\end{array}$ & $\begin{array}{c}1.54 \\
(0.16)^{\mathrm{cd}}\end{array}$ & $\begin{array}{c}3.14 \\
(0.34)^{\mathrm{b}}\end{array}$ & $\begin{array}{c}1.86 \\
(0.14)^{\mathrm{c}}\end{array}$ & $\begin{array}{c}3.69 \\
(0.36)^{\mathrm{a}}\end{array}$ & $\begin{array}{c}1.24 \\
(0.09)^{\mathrm{d}}\end{array}$ & $\begin{array}{c}3.16 \\
(0.09)^{\mathrm{ab}}\end{array}$ & $\begin{array}{c}3.21 \\
(0.27)^{\mathrm{ab}}\end{array}$ & $30.78 * * *$ \\
\hline & $360 \mathrm{~h}$ & $\begin{array}{c}0.99 \\
(0.78)^{\mathrm{b}}\end{array}$ & $\begin{array}{c}0.55 \\
(0.05)^{\mathrm{b}}\end{array}$ & $\begin{array}{c}2.17 \\
(0.12)^{\mathrm{a}}\end{array}$ & $\begin{array}{c}0.73 \\
(0.03)^{b}\end{array}$ & $\begin{array}{c}0.84 \\
(0.02)^{b}\end{array}$ & $\begin{array}{c}0.16 \\
(0.02)^{b}\end{array}$ & $\begin{array}{c}2.13 \\
(0.04)^{\mathrm{a}}\end{array}$ & $\begin{array}{c}0.71 \\
(0.06)^{b}\end{array}$ & $6.92 * *$ \\
\hline & $t$ & $1.06^{\mathrm{ns}}$ & $8.58^{*}$ & $3.75^{\mathrm{ns}}$ & $11.01 * *$ & $11.29 * *$ & $17.06^{* * *}$ & $14.86^{* * *}$ & $12.45^{* *}$ & - \\
\hline \multirow[t]{3}{*}{ Cellulose (\%) } & $0 \mathrm{~h}$ & $\begin{array}{c}2.53 \\
(0.38)^{\mathrm{b}}\end{array}$ & $\begin{array}{c}3.28 \\
(0.26)^{\mathrm{a}}\end{array}$ & $\begin{array}{c}1.46 \\
(0.16)^{\mathrm{e}}\end{array}$ & $\begin{array}{c}2.02 \\
(0.18)^{\mathrm{cd}}\end{array}$ & $\begin{array}{c}1.80 \\
(0.17)^{\text {cde }}\end{array}$ & $\begin{array}{c}2.16 \\
(0.05)^{\mathrm{bc}}\end{array}$ & $\begin{array}{c}3.09 \\
(0.09)^{\mathrm{a}}\end{array}$ & $\begin{array}{c}1.57 \\
(0.14)^{\mathrm{de}}\end{array}$ & $22.33 * * *$ \\
\hline & $360 \mathrm{~h}$ & $\begin{array}{c}3.35 \\
(0.13)^{\mathrm{f}}\end{array}$ & $\begin{array}{c}6.55 \\
(0.25)^{\mathrm{bc}}\end{array}$ & $\begin{array}{c}7.16 \\
(0.09)^{\mathrm{a}}\end{array}$ & $\begin{array}{c}6.13 \\
(0.02)^{d}\end{array}$ & $\begin{array}{c}4.86 \\
(0.10) \mathrm{e}\end{array}$ & $\begin{array}{c}6.01 \\
(0.17)^{\mathrm{d}}\end{array}$ & $\begin{array}{c}6.83 \\
(0.17)^{\mathrm{b}}\end{array}$ & $\begin{array}{c}6.22 \\
(0.10)^{\mathrm{cd}}\end{array}$ & $146.85^{* *}$ \\
\hline & $t$ & $2.88^{\mathrm{ns}}$ & $12.80^{* *}$ & $44.22 * * *$ & $32.31 * *$ & $21.61 * *$ & $30.91 * *$ & $27.43 * *$ & $38.79 * * *$ & \\
\hline \multirow[t]{3}{*}{ Lignin (\%) } & $0 \mathrm{~h}$ & $\begin{array}{c}5.37 \\
(1.44)^{\mathrm{a}}\end{array}$ & $\begin{array}{c}3.25 \\
(1.06)^{\mathrm{a}}\end{array}$ & $\begin{array}{c}1.05 \\
(0.44)^{\mathrm{a}}\end{array}$ & $\begin{array}{c}3.47 \\
(0.71)^{\mathrm{a}}\end{array}$ & $\begin{array}{c}3.22 \\
(1.24)^{\mathrm{a}}\end{array}$ & $\begin{array}{c}2.27 \\
(0.94)^{\mathrm{a}}\end{array}$ & $\begin{array}{c}3.01 \\
(0.97)^{\mathrm{a}}\end{array}$ & $\begin{array}{c}2.57 \\
(0.21)^{\mathrm{a}}\end{array}$ & $3.29 \mathrm{~ns}$ \\
\hline & $360 \mathrm{~h}$ & $\begin{array}{c}13.44 \\
(0.88)^{\mathrm{a}}\end{array}$ & $\begin{array}{c}7.70 \\
(0.33)^{\mathrm{cd}}\end{array}$ & $\begin{array}{c}4.69 \\
(0.77)^{g}\end{array}$ & $\begin{array}{c}9.76 \\
(0.13)^{b}\end{array}$ & $\begin{array}{c}6.15 \\
(0.13)^{\mathrm{ef}}\end{array}$ & $\begin{array}{c}5.04 \\
(0.97)^{\mathrm{fg}}\end{array}$ & $\begin{array}{c}6.94 \\
(0.17)^{\mathrm{de}}\end{array}$ & $\begin{array}{c}8.37 \\
(0.14)^{\mathrm{c}}\end{array}$ & $51.88 * * *$ \\
\hline & $t$ & $6.77 *$ & $5.69^{*}$ & $5.78^{*}$ & $12.33 * *$ & $3.34^{\mathrm{ns}}$ & $2.90^{\mathrm{ns}}$ & $5.66^{*}$ & $32.59 * * *$ & - \\
\hline
\end{tabular}

Changes in water content of leaf litter The WC of litter increased rapidly during the first $6 \mathrm{~h}$ of immersion, reaching 52.57 and $183.86 \%$ of dry mass respectively in $S$. g. guineense and $V$. madiensis (Fig. 1). Then the rate of increase slowed. At the end of incubation (15 days), the WC varied from $162.77 \%$ in $S$. g. macrocarpum to $264.51 \%$ in $V$. madiensis. Maximum water content (or maximum capacity of litter imbibition) was reaching after $72 \mathrm{~h}$ for the litter of $A$. senegalensis, $L$ lanceolata, $S$. g. macrocarpum, $V$. paradoxa, $V$. madiensis and $X$. americana, because the values of water content among the four last sampling times were not significantly different $(\mathrm{P}>0.05)$. Nevertheless, $V$. doniana and $S$. g. guineense reached their maximum water content respectively after 24 $\mathrm{h}$ and $240 \mathrm{~h}$.

The water absorption was fitted to an exponential model for each litter type. All the fits were highly significant (Tab. 2). The absorption process seemed to have been completed at the end of 15 days, since the WC reached values which were not significantly different from the asymptote values (A) for all species $(\mathrm{P}<0.05)$. The multiple comparison of asymptote values (A) and water absorption rate constants $\left(k_{\mathrm{e}}\right)$ by $T^{\prime}$-method a t $5 \%$ (Sokal \& Rohlf 1981) showed significant differences among species (Tab. 2). V. madiensis was distinguished by the highest asymptote value and the highest absorption rate; both Syzygium species showed the lowest asymptote values, together with $V$. paradoxa and $X$. americana, and the lowest absorption rate constant.

\section{Changes in LMR}

The LMR of all species decreased rapidly from 81.1 to $97.6 \%$ in the first $24 \mathrm{~h}$ respectively in X. americana and L. lanceolata (Fig. 2). For all species, half of the mass loss by leaching occurred within 3 days $(72 \mathrm{~h})$. After 15 days of immersion in water, the LMR varied from 66 to $90 \%$ of its initial mass, respectively in the same previous species, corresponding to a mass loss between 34 and $10 \%$ of their initial mass.

The LMR was fitted to negative exponential model, with a highly significant coefficient of determination for all species (Tab. 2). A multiple comparison of leaching rate constants $\left(k_{\mathrm{s}}\right)$ and water soluble compartment (B) by T'-method (Sokal \& Rohlf, 1981) showed that the changes in mass loss during the leaching experiment varied among species. $V$. madiensis had the highest leaching rate constant and L. lanceolata and both Syzygium species the lowest ones. Nevertheless, $X$. americana distinguished itself by the highest water soluble substance compartment and $L$. lanceolata and $V$. paradoxa by the lowest ones.

\section{Changes in organic compounds}

The chemical composition (\%) of litter generally changed by differential losses or gains of its compounds during $360 \mathrm{~h}$ of leaching (Tab. 1). However, in some species no change was observed in water-soluble sugars (S. g. macrocarpum), cellulose ( $L$. lanceolata), phenol (L. lanceolata and $V$. paradoxa) and lignin (S.g. macrocarpum and $V$. madiensis). Organic compounds changes after 168 and $360 \mathrm{~h}$ of litter leaching were presented in Fig. 3. The quantity of watersoluble sugars and phenol compounds decreased significantly during leaching in seven species (Fig. 3 and Tab. 3): $48-83 \%$ of water-soluble sugars and $40-89 \%$ of phenol were leached after 15 days of immersion in water, i.e. $0.21-0.50 \mathrm{~g}$ of sugars and 0.06 $0.05 \mathrm{~g}$ of phenol, respectively in $A$. senega- 
Tab. 2 - Exponential regression equations describing changes in litter WC (in \% dry mass) and LMR (in \% of the initial mass) with leaching time (in hour). For each parameter, different letters indicate that the values are significantly different between plants species (P \&lt; 0.05, T' method). All coefficients of determination $\left(\mathrm{R}^{2}\right)$ are significant at $\mathrm{P} \& 1 \mathrm{lt} ; 0.001$. Standard Error in parenthesis and $\mathrm{n}=21$. AS: A. senegalensis; LL: L. lanceolata; SG: Syzygium guineense var. guineense; SM: S. guineense var. macrocarpum; VD: V. doniana; VM: V. madiensis; VP: V. paradoxa and XA: X. americana.

\begin{tabular}{|c|c|c|c|c|c|c|c|}
\hline \multirow{2}{*}{ Species } & \multicolumn{3}{|c|}{$W C=A\left[1-\exp \left(-k_{e} t\right)\right]$} & \multicolumn{4}{|c|}{$L M R=B * \exp \left(-k_{s} t\right) C$} \\
\hline & $\mathbf{A}$ & $\mathbf{k}_{\mathrm{e}}$ & $\mathbf{R}^{2}$ & B & C & $\mathbf{k}_{\mathrm{s}}$ & $\mathbf{R}^{2}$ \\
\hline LL & $187.49(4.26)^{\mathrm{bc}}$ & $0.11(0.01)^{\mathrm{bc}}$ & 0.955 & $9.37(1.01)^{\mathrm{c}}$ & $89.95(1.05)^{\mathrm{a}}$ & $0.007(0.002)^{\mathrm{d}}$ & 0.920 \\
\hline VD & $200.81(4.01)^{\mathrm{b}}$ & $0.23(0.03)^{\mathrm{ab}}$ & 0.958 & $12.02(0.82)^{\mathrm{bc}}$ & $86.58(0.52)^{\mathrm{a}}$ & $0.048(0.011)^{\mathrm{bc}}$ & 0.911 \\
\hline VP & $165.67(3.73)^{d}$ & $0.15(0.02)^{\mathrm{abc}}$ & 0.954 & $9.95(1.16)^{\mathrm{c}}$ & $88.82(0.61)^{\mathrm{a}}$ & $0.119(0.048)^{\mathrm{ab}}$ & 0.787 \\
\hline AS & $171.05(4.27)^{\mathrm{cd}}$ & $0.16(0.02)^{\mathrm{ab}}$ & 0.939 & $12.10(0.70)^{\mathrm{bc}}$ & $86.51 \mathrm{a}(0.56)^{\mathrm{a}}$ & $0.020(0.003)^{\mathrm{bcd}}$ & 0.937 \\
\hline SM & $154.63(3.77)^{\mathrm{d}}$ & $0.08(0.01)^{\mathrm{bc}}$ & 0.954 & $10.73(1.98)^{\mathrm{bc}}$ & $87.97(2.08)^{\mathrm{a}}$ & $0.006(0.003)^{\mathrm{d}}$ & 0.837 \\
\hline VM & $242.31(4.66)^{\mathrm{a}}$ & $0.32(0.04)^{\mathrm{a}}$ & 0.959 & $15.57(1.02)^{\mathrm{b}}$ & $83.50(0.47)^{\mathrm{b}}$ & $0.252(0.053)^{\mathrm{a}}$ & 0.923 \\
\hline XA & $165.99(3.61)^{\mathrm{d}}$ & $0.17(0.02)^{\mathrm{ab}}$ & 0.958 & $28.33(1.32)^{\mathrm{a}}$ & $69.71(0.88)^{c}$ & $0.036(0.006)^{\mathrm{bc}}$ & 0.956 \\
\hline SG & $165.95(4.50)^{\mathrm{d}}$ & $0.03(0.004)^{\mathrm{c}}$ & 0.956 & $13.30(1.33)^{\mathrm{bc}}$ & $85.97(1.37)^{\mathrm{ab}}$ & $0.008(0.002)^{\mathrm{d}}$ & 0.919 \\
\hline
\end{tabular}

lensis and $V$. paradoxa for sugars and in $V$. paradoxa and $V$. madiensis for phenol. In contrast, cellulose and lignin increased during the same process in the all species, with differences not always significant (Tab. 3 ): $46-322 \%$ of cellulose and $98-283 \%$ of lignin were gained after 15 days of immersion in water, i.e. $0.07-0.22 \mathrm{~g}$ of cellulose, respectively in $X$. americana and $V$. paradoxa, and $0.15-0.14 \mathrm{~g}$ of lignin respectively, in $V$. doniana and $V$. paradoxa.

Correlations between water absorption and leaching rate constants and initial litter properties

The asymptote of the absorption exponential model (or maximum water content $=$ MWC) was correlated positively with watersoluble sugar contents and negatively with phenol contents of initial litter (Tab. 4). The water absorption rate constant $\left(k_{\mathrm{e}}\right)$ was positively correlated with initial litter area and water-soluble sugars and negatively correlated with phenol content of initial litter. The compartment of water-soluble substance (MSS) was negatively correlated with litter area, while the leaching rate constant $\left(k_{\mathrm{s}}\right)$ was positively correlated with water-soluble sugars. It was also correlated with maximum water absorption capacity (or maximum water content $=$ MWC) of litter:

$$
\begin{gathered}
k_{s}=-0.3717+2.38 \cdot 10^{3} \cdot M W C \\
R^{2}=0.7853, P=0.0209, n=8
\end{gathered}
$$

The water content of litter at the end of the leaching experiment was not correlated with the total mass loss. Nevertheless there was significant correlation between the absorption rate constant $\left(k_{\mathrm{e}}\right)$ and the leaching rate constant $\left(k_{\mathrm{s}}\right)$ of the litter $\left(\mathrm{R}^{2}=0.8011, \mathrm{P}<\right.$ $0.005, \mathrm{n}=8$ ). The stepwise model showed that the relationship between water absorption rate constant $\left(k_{\mathrm{e}}\right)$ and initial litter properties was explained about $90 \%$ by the association of litter thickness and water-soluble sugars:

$$
\begin{gathered}
k_{e}=-0.1645+0.1172 \cdot \text { thickness } \\
+0.0296 \cdot \text { sugars } \\
R^{2}=0.9034, P<0.001, n=8
\end{gathered}
$$

The relationship between leaching rate constant $\left(k_{\mathrm{s}}\right)$ and initial litter properties was explained about $95 \%$ by the association of water-soluble sugars and initial water content of initial litter:

$$
\begin{gathered}
k_{s}=-0.5983+0.0384 \cdot \text { sugars } \\
+0.05176 \cdot I W C \\
R^{2}=0.9503, P<0.001, n=8
\end{gathered}
$$

\section{Discussion and conclusions}

Water absorption and mass loss were rapid at the start of incubation for all species. The dynamics of each of the both processes slowed until $72 \mathrm{~h}$ when the water absorption and the litter mass loss reached their maximum. No data from litter of African tropical savannas was available in literature, excepting that of Ibrahima et al. (2003). Their study found that the water content of nine species of sudano-guinea savanna of Adamawa, including the eight species under present study varied from 104 to $240 \%$ of dry mass respectively for $S$. g. var. guin-

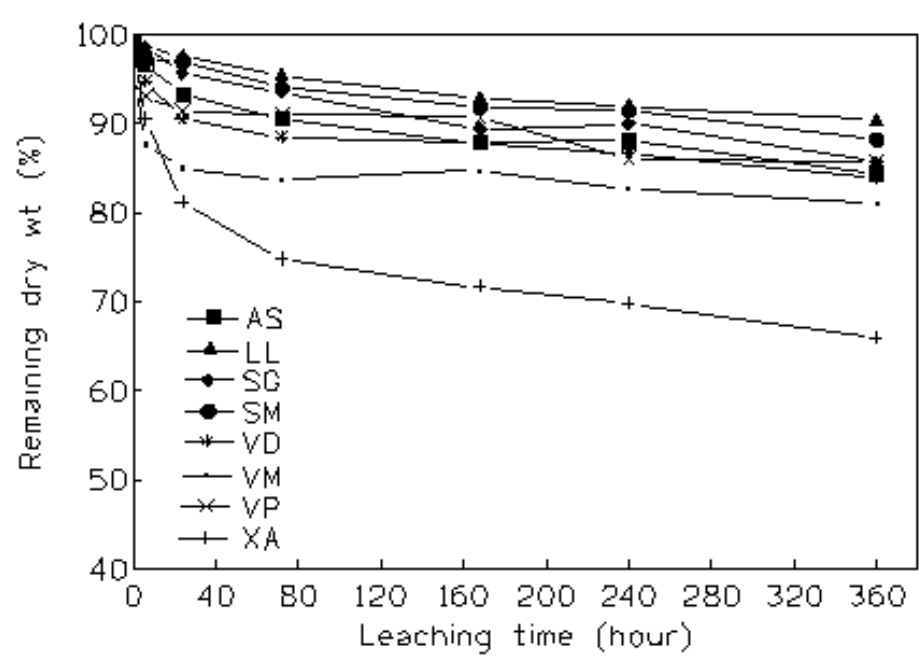

eense and Uapaca togoensis during $24 \mathrm{~h}$ of leaching in laboratory, and from 173 to $335 \%$ for the same species at the end of experiment $(240 \mathrm{~h})$. The mass loss varied between 5 and $28 \%$ of initial dry mass respectively for $V$. paradoxa and X. americana during $24 \mathrm{~h}$ of leaching and from 12 and $33 \%$ for the same species during $240 \mathrm{~h}$ of leaching. In the present study, the litter water content varied from $88.21 \%$ (S. g. var. guineense) to $226.90 \%$ ( $V$. madiensis), in $24 \mathrm{~h}$, from 158.66 ( $S$. $g$. var. macrocarpum) to $245.85 \%$ ( $V$. madiensis), in $240 \mathrm{~h}$, and from $162.77 \%$ to $264.52 \%$ of their dry mass in the same species at the end of the experiment (after $360 \mathrm{~h}$ ). The mass loss varied from $2.39 \%$ (L. lanceolata) to 18.87 (X. americana), in $24 \mathrm{~h}$, from 8.00 to $30.17 \%$, in $240 \mathrm{~h}$, and from 9.61 to $34.12 \%$ in the same species at the end of the experiment $(360 \mathrm{~h})$. The difference between the two results were significant $(\mathrm{P}<0.05)$ for eight species (not including $U$. togoensis) during $240 \mathrm{~h}$ of leaching, despite the two occurred in the different period.

Similar results were reported by Nykvist (1959a, 1959b; 1963), Taylor \& Parkinson (1988), Parsons et al. (1990) and Ibrahima et
Fig. 2 - Changes in litter mass with leaching time in the 8 agroforestry species studied. AS: A. senegalensis; LL: L. lanceolata; SG: S.g. guineensis; SM: S. g. macrocarpum; VP: $V$. paradoxa; VD: V. doniana; VM: $V$. madiensis; $\mathrm{XA}: X$. americana. 

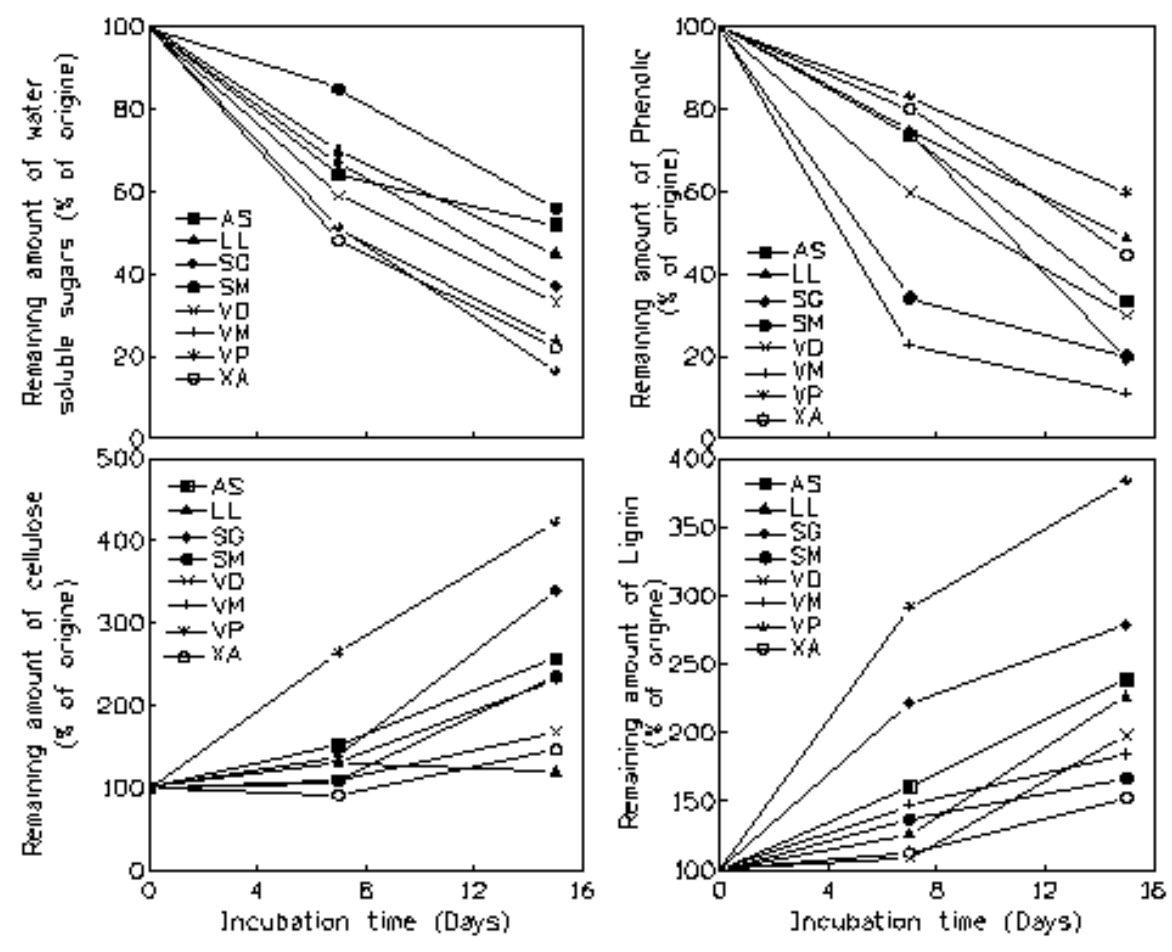

Fig. 3 - Changes in litter organic compounds (water soluble sugars, phenol, cellulose and lignin) with leaching time in the 8 agroforestry species studied. AS: A. senegalensis; LL: $L$. lanceolata; SG: S.g. guineensis; SM: S. g. macrocarpum; VP: V. paradoxa; VD: V. doniana; VM: V. madiensis; XA: X. americana.

al. (1995) on the leaf litter leaching of Temperate and Mediterranean broad-leaved species. According to Taylor \& Parkinson (1988), the water absorption and the litter mass loss of trembling aspen (Populus tremuloides), in $24 \mathrm{~h}$, were respectively $300 \%$ of litter dry mass (either about $90 \%$ of maximum water absorption capacity) and $24 \%$ of initial dry mass. Ibrahima et al. (1995) also have found that the litter of six Mediterranean tree species have the water absorption capacity ranging from $98 \%$, in Quercus ilex, to $250 \%$, in Castanea sativa, in $24 \mathrm{~h}$ of in- cubation, reaching, in $240 \mathrm{~h}$ of incubation, $155 \%$ and $362 \%$ of dry mass, respectively. The mass loss varied from $3.2 \%$, in Fagus sylvatica, to $6 \%$ of their initial mass, in Castanea sativa, during $24 \mathrm{~h}$ of incubation, and from $7 \%$ to $15 \%$ in the same species during $240 \mathrm{~h}$ of incubation.

Leaf Litter of Sudano-guinea Savannas of Ngaoundere seemed to have different patterns of water absorption and leaching than those of Temperate and Mediterranean regions. The Temperate leaf litters (Castanea sativa and Populus tremuloides) have high water absorption capacity and high absorption and leaching rate constants. Water absorption and mass loss were almost completed (reached $90 \%$ of water absorption capacity) in $24 \mathrm{~h}$ of leaching in Populus tremuloides, Fraxinus excelci or and Castanea sativa (Nykvist 1963, Taylor \& Parkinson 1988, Ibrahima et al. 1995), while in the Mediterranean and Sudano -guinea Savannas species, water absorption and mass loss slowed down and reached their maximum capacity around $72 \mathrm{~h}$, even $240 \mathrm{~h}$ of incubation time varying with the species. Nevertheless, water -soluble substances (or maximum mass loss) of Sudano -guinea Savannas leaf litters $(31 \%$ of initial dry mass in $240 \mathrm{~h})$ were about 1.3 and 2 times higher than those of the Temperate (24\%) and Mediterranean (15\%) species, respectively. These results were in conformity with those reported by Jung et al. (1968) in their studies on the comparison among some litters of Temperate species (Calluna vulgaris, Festuca sylvatica and Fagus sylvatica) and Tropical species (Acacia albida, Guiera senegalensis, Khaya senegalensis and Gmelina arborea) of the dry Sahel-Senegalian Savannas. They have shown that the litters of tropical species were generally richer in water-soluble substances than those of temperate species. Other studies (Bernhard-Reversat 1993, Bernhard-Reversat 1999) had shown that Eucalyptus and Acacia auriculiformi leaf litters, originating from the Australian region and now largely planted in the African Savannas, exhibited a high content of soluble organic matter, ranging from $30 \%$ to $35 \%$ of dry mass. This suggested that the leaching role (or initial phase of litter decomposition) possibly has an important implication in the litter decomposition processes of Sudano -guinea Savannas, insofar as it is in this stage that energetic substances, such as water-soluble sugars, necessary for the biological activities, were mostly released.

According to the study of Ibrahima et al.

Tab. 3 - Mean differences in organic compound amounts between initial and final litter ( $360 \mathrm{~h}$ of incubation) expressed in $\mathrm{g}$ and, if these differences were significant, also as percentage of the initial amount. ND: non determined; ns: non significant; * P \&lt; 0.05; ** P \&lt; 0.01; *** P \&1t; 0.001. Gain ( ) and loss (-). AS: A. senegalensis; LL: L. lanceolata; SG: Syzygium guineense var. guineense; SM: S. guineens e var. macrocarpum; VD: V. doniana; VM: V. madiensis; VP: V. paradoxa and XA: X. americana.

Deciduous broad-leaved trees

Deciduous broad-leaved shrubs

Evergreen

Parameter

(1)

Deciduous broad-leaved shrubs

broad-leaved

\begin{tabular}{|c|c|c|c|c|c|c|c|c|c|}
\hline & & & & & & & & \multicolumn{2}{|r|}{ 11, } \\
\hline & & $\mathbf{L L}$ & VD & VP & $\mathbf{A S}$ & SM & $\mathbf{V M}$ & $\mathbf{X A}$ & SG \\
\hline Litter mass & $\% \mathrm{~g}$ & $-9.61 * * *$ & $-16.09 * * *$ & $-14.17 * * *$ & $-15.56 * * *$ & $-11.8 * * *$ & $-18.89 * * *$ & $-34.12 * * *$ & $-14.27 * * *$ \\
\hline \multirow[t]{2}{*}{ Soluble sugars } & $\mathrm{G}$ & $-0.20^{*}$ & $-0.33 * *$ & $-0.50 * *$ & $-0.21 * * *$ & $-0.12 \mathrm{~ns}$ & $-0.40 * *$ & $-0.41 *$ & $-0.20 *$ \\
\hline & $\%$ & 54.05 & 66.84 & 83.24 & 47.98 & ND & 75.44 & 77.40 & 65.58 \\
\hline \multirow[t]{2}{*}{ Phenol } & $\mathrm{G}$ & $-0.04 n s$ & $-0.05 * *$ & $-0.06^{*}$ & $-0.06^{* *}$ & $-0.14 * *$ & $-0.05 * * *$ & $-0.08 * *$ & $-0.12 * *$ \\
\hline & $\%$ & ND & 70.23 & 40.40 & 66.60 & 80.05 & 89.19 & 55.36 & 81.00 \\
\hline Cellulose & G & $0.02 \mathrm{~ns}$ & $0.10^{*}$ & $0.22 * * *$ & $0.15 * * *$ & $0.11 * *$ & $0.13^{* * *}$ & $0.07 *$ & $0.18 * * *$ \\
\hline \multirow[t]{2}{*}{ Lignin } & $\mathrm{G}$ & $0.33 *$ & $0.15^{*}$ & $0.14^{*}$ & $0.23 *$ & $0.10 \mathrm{~ns}$ & $0.09 \mathrm{~ns}$ & $0.08 \mathrm{~ns}$ & $0.22 * *$ \\
\hline & $\%$ & 126.60 & 97.93 & 283.10 & 138.50 & $\mathrm{ND}$ & ND & ND & 178.9 \\
\hline
\end{tabular}


(1995), the litters of deciduous species as Castanea sativa and Fagus sylvatica were distinguished from these of evergreen species like Quercus ilex and Quercus coccifera by their higher water absorption and higher mass loss during 10 days of laboratory leaching experiment in darkness. Conversely, no net differences were revealed in this study, among evergreen (S. g. guineense) and deciduous species (all remaining species), among forestry gallery species $(S . g$. guineense, $V$. doniana) and dry upland Savanna species (A. senegalensis, L. lanceolata, $S$. g. macrocarpum, $V$. madiensis, $V$. paradoxa and $X$. americana), nor among tree species (L. lanceolata, S. g. guineense, $V$. doniana and $V$. paradoxa) and shrubs ones (A. senegalensis, $S$. g. macrocarpum, V. madiensis, $X$. americana) according to water absorption capacity and water-soluble substance loss by their litters during $360 \mathrm{~h}$ of leaching. But, differences among plant families and among plant species seemed to appear in the present study. In fact, water absorption and release of water-soluble substances rate constants of Myrtaceae (S. g. guineense and S. g. macrocarpum) were slower than those of Verbenaceae ( $V$. doniana and $V$. madiensis). In the same way, leaf litter of $X$. americana was richer in water-soluble substances than those of other species, while water absorption rate constant showed the highest value in $V$. madiensis and the lowest one in S. g. guineense, L. lanceolata and S. g. macrocarpum This difference among species was reported by Jung et al. (1968) who studied the quality (but not the quantity) of water-soluble substances in the various types of litter. They thus showed that the litter of Acacia albida is richer in reducing sugars and contains relatively low amounts of amino -nitrogen than Khaya senegalensis and Gmelina senegalensis. They demonstrated that the supplementary contribution of Acacia leaves entails a marked enriching in all the water-soluble compounds of a little-leached tropical ferruginous soil. According to these authors, this fact partially explains the favourable influence of Acacia on the biological activities of the soil, proven in previous works (Jung 1967) and on the output of crops, reported by Charreau \& Vidal (1965).

Generally the physical features of leaf-litter as well as their chemical quality seemed to play a great role in the changes in water absorption and water soluble substances, as reported by Taylor \& Parkinson (1988), Saini (1989) and Ibrahima et al. (1995). The maximum water absorption (A) and its rate constant $\left(k_{\mathrm{e}}\right)$ were positively influenced by litter area and thickness and water-soluble sugars, and negatively affected by initial phenol content, while litter mass loss (MSS) and their rate constants $\left(k_{\mathrm{s}}\right)$ were negatively influenced by litter area and positively affected by water soluble sugars and initial water

Tab. 4 - Correlation coefficients of Pearson $(n=8)$ calculated between initial litter properties and maximum water content $(M W C)$, maximum water soluble substances $(M S S)$ and water absorption and leaching rate constants. In bold significant $(\mathrm{P}<0.05$ or $\mathrm{P}<0.01)$ correlations.

\begin{tabular}{lcccc}
\hline \multicolumn{1}{c}{ Parameter } & MWC & $\mathbf{k}_{\mathbf{e}}$ & \multicolumn{1}{c}{ MSS } & \multicolumn{1}{c}{$\mathbf{k}_{\mathbf{s}}$} \\
\hline Thickness (mm) & 0.2095 & 0.1923 & -0.3767 & -0.0722 \\
Area $\left(\mathrm{cm}^{2}\right)$ & -0.3876 & 0.9420 & -0.7858 & -0.3679 \\
Initial WC (\%) & -0.4179 & -0.5331 & -0.6753 & -0.1889 \\
Water-soluble sugars (\%) & 0.7891 & 0.9420 & 0.3752 & 0.8611 \\
Phenol (\%) & -0.8245 & -0.7173 & 0.1973 & -0.3932 \\
Cellulose \%) & -0.0066 & 0.4251 & 0.4152 & 0.3518 \\
Lignin (\%) & -0.0407 & -0.3531 & -0.1162 & -0.6021 \\
\hline
\end{tabular}

content of litter. During the 15 days of immersion in water, while at the same time absorbed water, the litter lost mass by releasing some of its constituents, which became dissolved in the water. But, no relation was found between the absolute value of water absorption by litters and their mass loss during leaching. This relationship exists between the rate constants of the two processes. These results did not agree with the findings of Ibrahima et al. (1995) on the Mediterranean litter types, because the authors reported that the initial cellulose content of litter seemed to play a role in the rate at which the litters absorbed water and the leaf thickness did not seem to have any influence on the dynamics of mass loss during leaching. On the other hand, in our study, litter thickness when it is combined with water-soluble sugars, seemed to influence the rate at which the litters absorbed water. Initial cellulose content did not play any role in the two processes in our study. Similarly, the quality index of initial lignin content of litters often considered as a determining factor for the overall speed of decomposition (e.g., Taylor et al. 1989, Bernhard-Reversat \& Schwartz 1997, Fioretto et al. 2001), did not seem to influence the dynamics of this leaching phase of decomposition. This is probably because decomposition mainly results from both physical, chemical and biological processes, but the leaching phase results only from physical and chemical processes (Ibrahima et al. 1995).

During the 15 days of leaching, the loss of dry mass was on average 9-34 $\mathrm{g}$ for each 100 $\mathrm{g}$ of initial litter. Among the C-rich constituents, soluble sugars and phenol were leached to a large extent: $48-83 \%$ and $40-89 \%$ of the sugars and phenol initially present in the litter disappeared during the 15 days of the experiment. This loss seemed to be proportional to the initial compound content of the litter. For instance, $V$. paradoxa, whose litter was the richest in soluble sugars and the poorest in cellulose and lignin content, had the lowest amounts in soluble sugars after 15 days after leaching. Comparatively, the quantity of lignin and cellulose in the litter increased during the 15 days of incubation. Metabolic compounds, which account for most of the constituents released by leaching, are molecules that are readily metabolized by micro-organisms; it is known that micro-organisms capable of degrading lignin compounds needed also other C sources (Berg \& Wessen 1984). Leaching of fresh litter can therefore lead to an export of these labile compounds towards the soil and therefore provide a supply of metabolic compounds for micro-organisms that participate in the decomposition processes of the underlying older litter layers. The mineral elements released by leaching are probably quickly recycled in the soil and vegetation. Leaching changed the chemical composition of the litters by lowering the water-soluble sugar concentration (significant in 7 species) and phenol concentration (significant in 6 species), and increasing the cellulose (significant in 7 species) and lignin (significant in 6 species) concentrations. These results agree with those of the literature. According to our results and those of Parsons et al. (1990) and Ibrahima et al. (1995), there is therefore a consistent trend in litter quality during leaching. Leaching may therefore have more important consequences for the subsequent decomposition processes in the Sudano-guinea Savannas of Ngaoundere, as well as in the tropical Savannas (BernhardReversat 1999), since it is known that the initial content of water-soluble substances plays a major role during litter decomposition. Berg \& Tamm (1991) and Berg \& Ekbohm (1991) showed that there is in fact a positive relation between the initial quantities of water-soluble substances in the litter and its rate of decomposition. Similarly, Mangenot \& Toutain (1980) demonstrated that the litter types that are richest in watersoluble substances are also those that are most quickly decomposed. We have also shown (Gillon et al. 1994) that the dynamics of mass loss during the decomposition of 12 Mediterranean litters in microcosms was largely explained by their initial content of water-soluble substances. Prolonged leaching could therefore transform fresh litter into 
a material that is less readily biodegradable. Parsons et al. (1990) demonstrated this. They showed that $P$ tremuloides litter that had been leached for 5 days subsequently decomposed much more slowly than intact litter. They also showed that the rate of mass loss from leaching litter was constant with time, whereas intact litter followed an exponential decline. According to the authors, this was probably due to the loss of a great proportion of the labile substances in the litter and therefore to the suppression at this stage of rapid mass loss at the start of decomposition.

In conclusion, the litters of the Sudanoguinea Savannas of Ngaoundere used in our study showed different capacities to release water-soluble substances during leaching. Three groups were distinguished: $X$. americ ana with the highest capacity to release water-soluble substances $(34.12 \%)$, in contrast, L. lanceolata and both Syzigiums showed the lowest capacity to release water-soluble substances $(9.61$ to $14.27 \%)$ and $A$. senegalensis and both Vitex (15.56 to $18.89 \%$ ) had intermediate patterns. The leaching rate constant of these litters was influenced by physical and chemical characteristics of original litters as reported in Temperate and Mediterranean biomes. Due to the high capacity to release water -soluble substances, such as water-soluble sugars, most of the Sudano -guinea Savannas litters have to be integrated into the farming systems to replace exotic plants species, as eucalyptus, whose water-soluble substances play a negative role in plant decomposition by slowing down the litter decomposition rate constant (BernhardReversat 1999, Bernhard-Reversat et al. 2003).

\section{Acknowledgements}

The research was supported partly by the University of Ngaoundere through of GPRU and partly by the International Foundation for Science (IFS), Stockholm, Sweden and United Nation University (UNU), Tokyo, Japan, through a grant to M. Adamou Ibrahima.

\section{References}

Berg B, Ekbohm G (1991). Litter mass-loss rates and decomposition patterns in some needle and leaf litter types. Long-term decomposition in a Scots pine forest VII. Canadian Journal of Botany 69: 1449-1456.

Berg B, Tamm CO (1991). Decomposition and nutrient dynamics of litter in long-term optimum nutrition experiments. Scandinavian Journal of Forestry Research 6: 305-321.

Berg B, Wessen B (1984). Changes in organicchemical components and in growth of fungal mycelium in decomposing birch leaf litter as compared to pine needles. Pedobiologia 26: 285 -
298.

Bernhard-Reversat F (1993). Dynamics of litter and organic matter at the soil-litter interface in fast-growing tree plantations on ferralitic soils (Congo). Acta Oecologica 14: 179-195.

Bernhard-Reversat F (1999). The leaching of eucalyptus hybrids and Acacia auriculiformis leaf litter: laboratory experiments on early decomposition and ecological implications in Congolese tree plantations. Applied Soil Ecology 12: 251261.

Bernhard-Reversat F, Main G, Holl K, Loumeto J, Ngao J (2003). Fast disappearance of the watersoluble phenolic fraction in eucalypt leaf litter during laboratory and field experiments. Applied Soil Ecology 23: 273-278.

Bernhard-Reversat F, Schwartz D (1997). Change in lignin content during litter decomposition in tropical forest soils (Congo): comparison of exotic plantations and native stands. C. R. Acad. Sci. Paris, Sciences de la terre et des planètes 325: 427-432.

Bossa JR, Adams JF, Shannon DA, Mullins GL (2005). Phosphorus and potassium release pattern from Leucaena leaves in three environment of Haiti. Nutrients Cycling in Agroecosystems 73: 25-35.

Charreau C, Vidal P (1965). Influence of Acacia albida Del. On soil mineral Nutrition and millet yield Pennisetum in Senegal. Agronomie Tropicale 600-625.

Cooke RC, Whipps JM (1993). Ecophysiology of Fungi. Blackwell Scientific. Oxford, UK.

Dubois M, Gilles KA, Hamilton JK, Robers PA, Smith F (1965). Colorimetry method for determination of sugar and related substances. Annales of Chemistry 28: 350-356.

Fioretto A, Papa S, Sorrentino G, Fuggi A (2001). Decomposition of Cistus incanus leaf litter in a Mediterranean maquis ecosystem: mass loss, microbial enzyme activities and nutrient changes. Soil Biology \& Biochemistry 33: 311-321.

Gillon D, Joffre R, Ibrahima A (1994). Initial litter properties and decay rate: a microcosm experiment on mediterranean species. Canadian Journal of Botany 72: 946-954.

Ibrahima A, Joffre R, Gillon D (1995). Changes in litter during the initial leaching phase: an experiment on the leaf litter of Mediterranean species. Soil Biology \& Biochemistry 27: 931-939.

Ibrahima A, Nguetnkam J-P, Hamawa Y, Todou G, Wanyaola B, Doba R (2003). Dynamics of water absorption and leaching of litter of nine agroforestry plant species of the Sudano-guinea savannas of Adamawa, Cameroon. Cameroon Journal of Academy of Sciences 3: 35-45.

Jung G, Bruckert S, Dommergues Y (1968). Etude comparée de diverses substances hydrosolubles extraites de quelques litières tropicales et tempérées. Oecologia Plantarum 3: 237-253.

Jung G (1967). Influence de l'Acacia albida sur la biologie des sols de DIOR. Rapport de l'ORSTOM, pp. 21.

Kalburtji KL, Mosjidis JA, Mamolos AP (1999).
Litter dynamics of low and high tannin Secea lespeza plants under field conditions. Plant Soil 208: 271-281.

MacLean DA, Wein RW (1978). Weight loss and nutrient changes in decomposing litter and forest floor material in New Brunswick forest stands. Canadian Journal of Botany 56: 2730-2749.

Mangenot F, Toutain F (1980). Les litières. Actualité d'Ecologie forestière: Sol, flore et faune. Gauthier - Villars, Paris, pp. 345.

Marigo G (1973). Méthode de fractionnement d'estimation des composés phénoliques chez les végétaux. Analysis pp. 106-110.

Nyckvist N (1959a). Leaching and decomposition of litter. I. Experiments on leaf litter of Fraxinus excelsior. Oïkos 10: 191-211.

Nyckvist N (1959b). Leaching and decomposition of litter. II. Experiments on leaf litter of Pine sylvestris. Oikos 10: 213-224.

Nykvist N (1963). Leaching and decomposition of water-soluble organic substances from différent types of leaf and needle litter. Studia Forestalia Suecica 3, Skogsbiblioteket, Stockholm.

Pabame P (2002). Indicateurs et gestion paysans de la fertilité des sols dans la région de Mbé, Adamaoua Cameroun. Mémoire de Maîtrise, Université de Ngaoundéré, Cameroun, pp. 49.

Parsons WFJ, Taylor BR, Parkinson D (1990). Decomposition of aspen (Populus tremuloides) leaf litter modified by leaching. Canadian Journal of Forestry Research 20: 943-951.

Saini RC (1989). Mass loss and nitrogen concentration changes during the decomposition of rice residues under field conditions. Pedobiologia 33: 229-235.

Sokal JR, Rohlf RR (1981). Biometry. W.H. Freeman \& Co. Editions, San Francisco, pp. 520.

Swift MJ, Heal OW, Anderson JM (1979). Decomposition in Terrestrial Ecosystems. Blackwell Scientific, Oxford, UK.

Taylor BR, Parkinson D (1988). Patterns of water absorption and leaching in Pine and Aspen leaf litter. Soil Biology \& Biochemestry 20: 257-258. Taylor BR, Parkinson D, Parsons WFJ (1989). Nitrogen and lignin content as predictors of litter decay rates: a microcosm test. Ecology 70: $97-$ 104.

Updegraff DM (1969). Semi-micro determinate of cellulose in biological material. Analytical biochemistry 32: 420-424.

van Soest PJ (1965). Use of detergent in analysis of fibrous feeds. III Study of effects of heating and drying on yield of fiber and lignin in forages. Journal of Association of Official Analytical Chemist 48: 785-790.

Waring RH, Schlesinger WH (1985). Forest ecosystems, concepts and management. Acad. Press. Inc., Orlando, USA, pp. 340.

Yonkeu S (1993). Végétation des pâturages de l'Adamaoua (Cameroun): écologie et potentialités pastorales. Thèse de Doctorat, Université de Rennes, France, pp. 207. 